\title{
Management of hypertension with fixed dose combinations of candesartan cilexetil and hydrochlorothiazide: patient perspectives and clinical utility
}

REVIEW

Thomas Mengden'

Sakir Uen'

Peter Bramlage ${ }^{2}$

'Centre of Vascular Medicine, Herz- und Gefäß-Campus, Bad Nauheim, Germany; ${ }^{2}$ nnstitute for Cardiovascular Pharmacology and Epidemiology, Mahlow, Germany
Correspondence: Thomas Mengden Centre of Vascular Medicine, Herz- und Gefäß-Campus Bad Nauheim, Ludwigstraße 4I, 6I23I Bad Nauheim, Germany

$\mathrm{Tel}+4960329995906$

Fax +496032999550

Email thomas.mengden@pitzer-kliniken.de
This article was published in the following Dove Press journal:

Vascular Health and Risk Management

30 November 2009

Number of times this article has been viewed

\begin{abstract}
Hypertension treatment and control is largely unsatisfactory when guideline-defined blood pressure goal achievement and maintenance are considered. Patient- and physician-related factors leading to non-adherence interfere in this respect with the efficacy, tolerability, and convenient use of pharmacological treatment options. Blockers of the renin-angiotensin system (RAS) are an important component of antihypertensive combination therapy. Thiazide-type diuretics are usually added to increase the blood pressure lowering efficacy. Fixed drug-drug combinations of both principles like candesartan/hydrochlorothiazide (HCTZ) are highly effective in lowering blood pressure while providing improved compliance, a good tolerability, and largely neutral metabolic profile. Comparative studies with losartan/HCTZ have consistently shown a higher clinical efficacy with the candesartan/HCTZ combination. Data on the reduction of cardiovascular endpoints with fixed dose combinations of antihypertensive drugs are however scarce, as are the data for candesartan/HCTZ. But many trials have tested candesartan versus a non-RAS blocking comparator based on a standard therapy including thiazide diuretics. The indications tested were heart failure and stroke and particular emphasis was put on elderly patients or those with diabetes. In patients with heart failure, for example, the fixed dose combination might be applied in patients in whom individual titration resulted in a dose of $32 \mathrm{mg}$ candesartan and $25 \mathrm{mg} \mathrm{HCTZ}$ which can then be combined into one tablet to increase compliance with treatment. Also in patients with stroke the fixed dose combination might be used in patients in whom maintenance therapy with both components is considered. Taken together candesartan/HCTZ assist both physicians and patients in achieving long-term blood pressure goal achievement and maintenance.
\end{abstract}

Keywords: chronic heart failure, stroke, diabetes, angiotensin receptor blocker, patients, physicians, persistence, compliance

\section{Background}

Hypertension is a highly prevalent risk factor for coronary heart disease (CHD), stroke, heart failure $(\mathrm{HF})$, renal disease, and recurrent cardiovascular events. It has been shown to reduce the number of life-years lost and the number of years lived with disability by 64.3 million globally. ${ }^{1}$ The European Society of Hypertension (ESH) classifies optimal blood pressure at $<120 \mathrm{mmHg}$ systolic blood pressure (SBP), and $<80 \mathrm{mmHg}$ diastolic blood pressure (DBP). ${ }^{2}$

A therapeutic reduction of elevated blood pressure (BP) levels has been shown to decrease cardiovascular morbidity and mortality. ${ }^{3}$ For the pharmacological management 
of hypertension, lowering BP below 140/90 $\mathrm{mmHg}$ in all patients is requested. Specific patients, those with diabetes mellitus or chronic kidney disease, need further BP reduction ( $<130 / 80 \mathrm{mmHg}$ or $<125 / 75 \mathrm{mmHg}$, respectively).

However these BP targets are difficult to meet despite the availability of a number of effective antihypertensive drugs. Consequently hypertension control is largely ineffective as the achievement of guideline defined treatment targets with about $20 \%$ of patients in Europe and up to $50 \%$ of patients in the US being finally controlled when treated. ${ }^{4,5}$ BP target achievement is even worse in patients with comorbid disease like diabetes mellitus.

\section{Patient perspective}

Hypertension is a rather unspectacular disease with unspecific symptoms that are, from a patient perspective, in many cases not perceived to occur in relation to hypertension. Patients therefore are reluctant to accept physicians' recommendations to adopt life-style changes (weight reduction, reduction of sodium intake, and increased physical activity), which are the recommended first steps in the treatment of hypertension.

It becomes even more difficult to convince patients for the need of action when antihypertensive pharmacotherapy is introduced. A number of patient-related factors leading to nonadherence like frequent dosing, ${ }^{6,7}$ drug-related adverse events (AEs), ${ }^{8}$ health beliefs, ${ }^{9}$ drug-drug interactions and associated medical conditions interfere with the patients' willingness to take drugs as prescribed. For an overview of terms used to describe adherence see Figure 1. Actually approximately half of the patients on antihypertensive drug therapy discontinue therapy by the end of the first year.

Hence, from a patient perspective, there is a need for effective, highly tolerable and convenient medication that does not interfere with daily life while controlling hypertension-associated risk.

\section{Physician perspective}

Recent data suggest that also physicians' attitudes and treatment strategies hamper the effectiveness of current therapy. ${ }^{10-12}$ In a recent global survey in a random sample of primary care physicians, $41 \%$ of physicians aimed to reduce BP to "acceptable levels" only, although generally agreeing with guideline recommended treatment goals. Physicians further believed that $62 \%$ of their patients had their BP controlled. However, in fact only $6 \%$ of patients with hypertension in the UK had their BP lowered to the recommended levels. ${ }^{13}$ In France, Germany, Italy, and Spain only 13\% of hypertensive patients have their BP controlled. ${ }^{14}$

The physicians' needs in the treatment of hypertension are partially overlapping with patients' needs. However, in the face of low patient compliance, the chronic nature of the disease, and increasing budget constraints, a possible solution seems to be difficult to determine.

\section{Treatment patterns}

Globally about one-third of patients receive monotherapy, one-third dual combination therapy, and one-third 3 or more

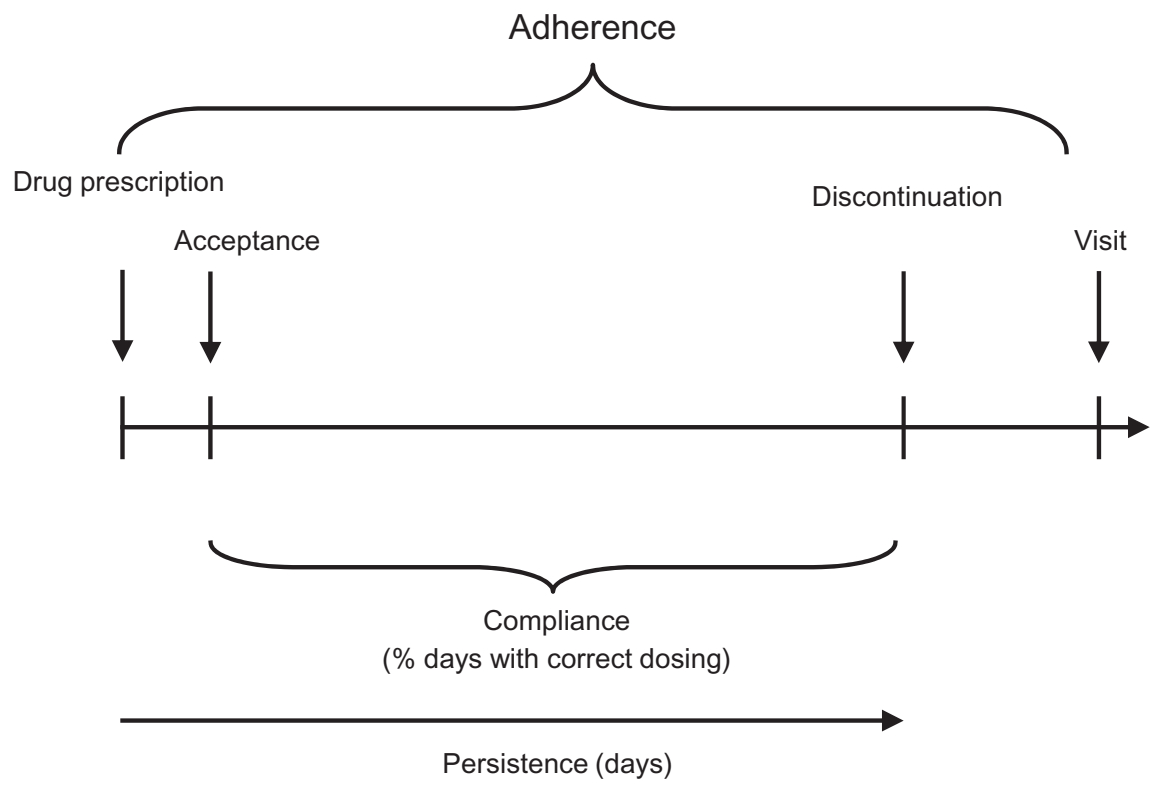

Figure I Terms used to describe adherence. 
antihypertensive drugs. The NICE for example calculated that $36 \%$ of patients in the UK receive monotherapy, $38 \%$ dual combination therapy, and $26 \% 3$ or more drug-drug combinations. ${ }^{15}$ In a recent drug utilization analysis in primary care in Germany, 29.2\% of treated patients received one, $43.7 \%$ received 2 , and $27.2 \%$ received 3 or more antihypertensive drugs. ${ }^{16}$

According to the aforementioned study ${ }^{16} 40.8 \%$ of patients in Germany received ACE inhibitors (ACEi), 36.1\% beta blockers, $31.7 \%$ diuretics, $22.3 \%$ calcium channel blockers (CCBs) and 14.1\% angiotensin receptor blockers (ARBs). ${ }^{16}$ Frequent drug-drug combinations were ACEi or ARBs in combination with diuretics, $\mathrm{CCBs}$, and beta blockers which is mostly in accordance with recent guidelines in which 4 out of 6 recommended combinations are ACEi/ARB based. ${ }^{17}$

\section{Guidelines}

The 2007 ESH/ESC guideline recognize 5 major antihypertensive drug classes - thiazide diuretics, CCBs, ACEi, ARBs, and betablockers - to be suitable for the initiation and maintenance of antihypertensive treatment. ${ }^{17}$ The JNC VII guidelines ${ }^{18}$ on the other hand recommend using thiazide diuretics first. Both guidelines agree however in recommending the use of particular drug classes based on the presence of compelling indications.

ACEi and ARBs are recommended for the largest variety of compelling indications (for a detailed overview see Table 1), with only minor compelling contraindications in patients with pregnancy, hyperkalemia, bilateral renal artery stenosis, and angioneurotic edema (ACEi only). Therefore both drug classes are used, as illustrated by data from different drug utilization studies, ${ }^{16,19}$ in $50 \%$ to $60 \%$ of patients.

\section{Drug-drug combination therapy}

According to the ESH/ESC guidelines, ${ }^{17}$ the following drug-drug combinations have been found to be effective and well tolerated in randomized efficacy trials: Thiazide diuretic plus $\mathrm{ACEi}$, thiazide diuretic and $\mathrm{ARB}, \mathrm{CCB}$ and $\mathrm{ACEi}, \mathrm{CCB}$ and $\mathrm{ARB}, \mathrm{CCB}$ and thiazide diuretic, and beta blocker and dihydropiridine CCBs. Thus, 4 out of 6 recommended dual antihypertensive combinations are ACEi/ARB based (Figure 2).

The ACCOMPLISH study triggered a lively discussion about the relative importance of drug-drug combinations..$^{20,21}$ It was designed to test whether benazepril $40 \mathrm{mg}$ combined with amlodipine $10 \mathrm{mg}$ would result in stronger cardiovascular event reduction than benazepril $40 \mathrm{mg} / \mathrm{HCTZ} 25 \mathrm{mg}$.
Inclusion and exclusion criteria favored the selection of patients with compelling indications for the use of CCBs. The composite primary endpoint of cardiovascular morbidity and mortality was reduced by $19.6 \%$ in patients receiving benazepril/amlodipine versus benazepril/HCTZ (9.6 versus 11.8\%; hazard ratio [HR] $0.80,95 \%$ CI $0.72-0.90)$. The secondary endpoint of death from cardiovascular causes, non-fatal myocardial infarction, and non-fatal stroke was reduced by $21 \%$ with a HR of 0.79 (95\% CI $0.67-0.92$ ). Side effects were generally however more frequent with amlodipine than with the thiazide diuretic. Unfortunately no similar comparative study of the ACCOMPLISH type exists for patients with compelling indications for thiazide diuretic use. ${ }^{22}$ At present the evidence base is weak for deciding which patient would benefit the most from either combination.

Law and Wald have suggested combining ACEi/ARBs with a low dose of any of the other drug classes to maximize BP lowering efficacy while maintaining a placebo-like tolerability. ${ }^{23}$ This recommendation was based on the metaanalytic observation that both ACEi and ARBs maintain a particular low AE profile in doses up to 4 times standard dose. On the contrary all other drug classes ( $\mathrm{CCBs}$, betablockers, thiazides) showed a steep incline of side effects at higher doses, while the tolerability was good at half-standard or even at standard dose.

The common approach to control BP in hypertensive patients is to titrate monotherapy to full dose and to add another agent if BP is still high (Figure 3, green). Drugs might be exchanged if there is indication of non-response to a particular agent. More recently the ESH/ESC guidelines ${ }^{17}$ introduced the concept of first-line combination therapy at low dose in patients with marked BP elevation, low target BPs, and high or very high cardiovascular risk (Figure 3, red). This has been shown to be effective and safe and tolerability of first-line combination therapy is excellent. ${ }^{24,25}$

\section{Requirements for antihypertensive drugs}

In summary, from a patient, physician, and societal perspective there is a clear need for drug-drug combinations which provide effective BP lowering, and display a low side effect profile and a high adherence of both physicians and patients with treatment. This would enable BP control to be increased considerably and would in turn not only save on hypertension-related morbidity (stroke, ischemic heart disease) and mortality but also on costs.

It has been calculated for the UK that achieving a systolic BP of $140 \mathrm{mmHg}$ on a large scale would decrease stroke 
Table I Compelling indications and contraindications in the use of antihypertensive drug classes ${ }^{17}$

\begin{tabular}{|c|c|c|}
\hline & Conditions favoring use & Compelling or possible contraindications \\
\hline Thiazide diuretics & $\begin{array}{l}\text { - Isolated systolic hypertension (elderly) } \\
\text { - Heart failure } \\
\text { - Hypertension in blacks }\end{array}$ & $\begin{array}{l}\text { - Gout } \\
\text { - Metabolic syndrome } \\
\text { - Glucose intolerance } \\
\text { - Pregnancy }\end{array}$ \\
\hline Beta blockers & $\begin{array}{l}\text { - Angina pectoris } \\
\text { - Post-myocardial infarction } \\
\text { - Heart failure } \\
\text { - Tachyarrhythmias } \\
\text { - Glaucoma } \\
\text { - Pregnancy }\end{array}$ & $\begin{array}{l}\text { - Asthma } \\
\text { - A-V block (grade } 2 \text { or } 3 \text { ) } \\
\text { - Peripheral artery disease } \\
\text { - Metabolic syndrome } \\
\text { - Glucose intolerance } \\
\text { - Athletes and physically active patients } \\
\text { - Chronic obstructive pulmonary disease }\end{array}$ \\
\hline Calcium antagonists (dihydropyridines) & $\begin{array}{l}\text { - Isolated systolic hypertension (elderly) } \\
\text { - Angina pectoris } \\
\text { - LV hypertrophy } \\
\text { - Carotid/coronary atherosclerosis } \\
\text { - Pregnancy } \\
\text { - Hypertension in blacks }\end{array}$ & $\begin{array}{l}\text { - Tachyarrhythmias } \\
\text { - Heart failure }\end{array}$ \\
\hline Calcium antagonists (verapamil/diltiazem) & $\begin{array}{l}\text { - Angina pectoris } \\
\text { - Carotid atherosclerosis } \\
\text { - Supraventricular tachycardia }\end{array}$ & $\begin{array}{l}\text { - A-V block (grade } 2 \text { or } 3 \text { ) } \\
\text { - Heart failure }\end{array}$ \\
\hline ACE inhibitors & $\begin{array}{l}\text { - Heart failure } \\
\text { - LV dysfunction } \\
\text { - Post-myocardial infarction } \\
\text { - Diabetic nephropathy } \\
\text { - Non-diabetic nephropathy } \\
\text { - LV hypertrophy } \\
\text { - Carotid atherosclerosis } \\
\text { - Proteinuria/microalbuminuria } \\
\text { - Atrial fibrillation } \\
\text { - Metabolic syndrome }\end{array}$ & $\begin{array}{l}\text { - Pregnancy } \\
\text { - Angioneurotic edema } \\
\text { - Hyperkalemia } \\
\text { - Bilateral renal artery stenosis }\end{array}$ \\
\hline Angiotensin receptor antagonists & $\begin{array}{l}\text { - Heart failure } \\
\text { - Post-myocardial infarction } \\
\text { - Diabetic nephropathy } \\
\text { - Proteinuria/microalbuminuria } \\
\text { - LV hypertrophy } \\
\text { - Atrial fibrillation } \\
\text { - Metabolic syndrome } \\
\text { - ACEi-induced cough }\end{array}$ & $\begin{array}{l}\text { - Pregnancy } \\
\text { - Hyperkalemia } \\
\text { - Bilateral renal artery stenosis }\end{array}$ \\
\hline Diuretics (antialdosterone) & $\begin{array}{l}\text { - Heart failure } \\
\text { - Post-myocardial infarction }\end{array}$ & $\begin{array}{l}\text { - Renal failure } \\
\text { - Hyperkalemia }\end{array}$ \\
\hline Loop diuretics & $\begin{array}{l}\text { - End stage renal disease } \\
\text { - Heart failure }\end{array}$ & \\
\hline
\end{tabular}




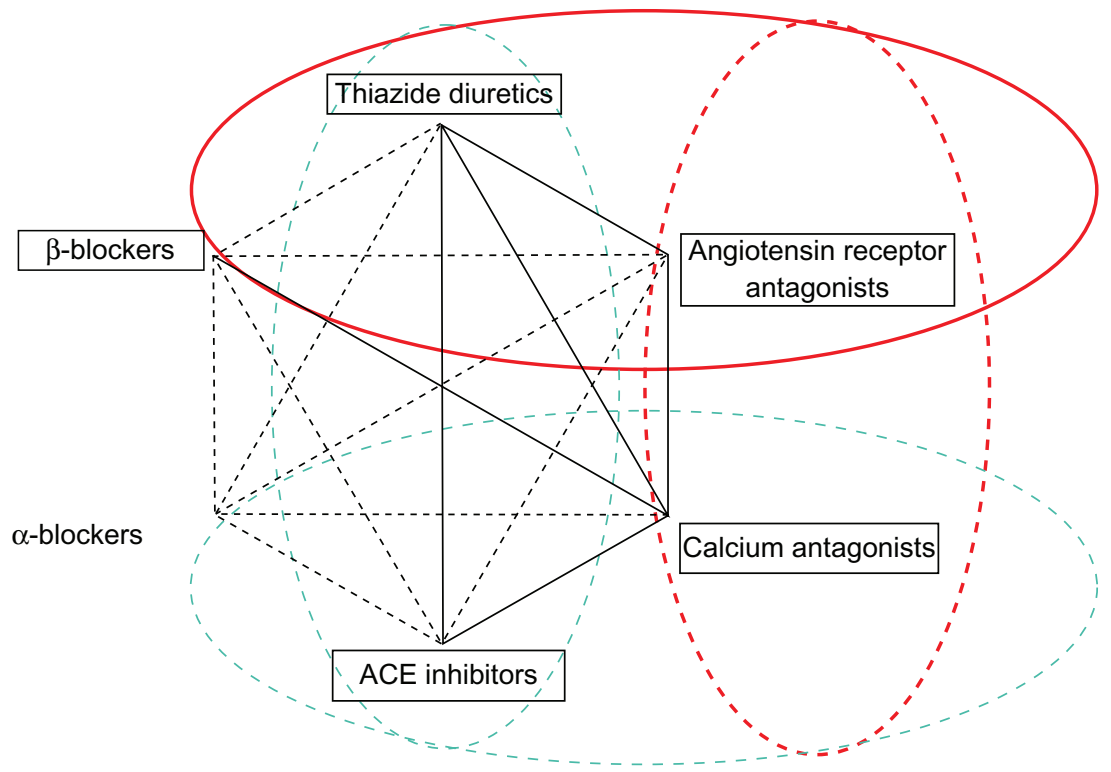

Figure 2 Four out of 6 recommended dual antihypertensive combination therapies include blockers of the renin-angiotensin system.

Notes: Red, recommendation including an angiotensin receptor blocker; green, recommendations including an ACE inhibitor.

Reproduced with permission from Mancia G, De Backer G, Dominiczak A, et al. Guidelines for the Management of Arterial Hypertension:The Task Force for the Management of Arterial Hypertension of the European Society of Hypertension (ESH) and of the European Society of Cardiology (ESC). J Hypertens. 2007; 25(6): I I05-I I 87. ${ }^{17}$ Copyright $(C)$ Lippincott Williams \& Wilkins.

incidence by up to $44 \%$ depending on age group considered and ischemic heart disease incidence up to $35 \% .{ }^{15}$ Assuming that a reduction of stroke incidence of $9 \%$ and ischemic heart disease of $4 \%$ across age groups might actually be achievable, the annual saving to the NHS would be $£ 255$ million for stroke and $£ 25$ million for ischemic heart disease while investing $£ 58$ million into drugs (net benefit to the NHS $£ 222$ million) (Figure 4).

\section{Candesartan/HCTZ}

The fixed drug-drug combination of candesartan cilexetil in a dose up to $32 \mathrm{mg}$ and HCTZ in a dose up to $25 \mathrm{mg}$ fulfils

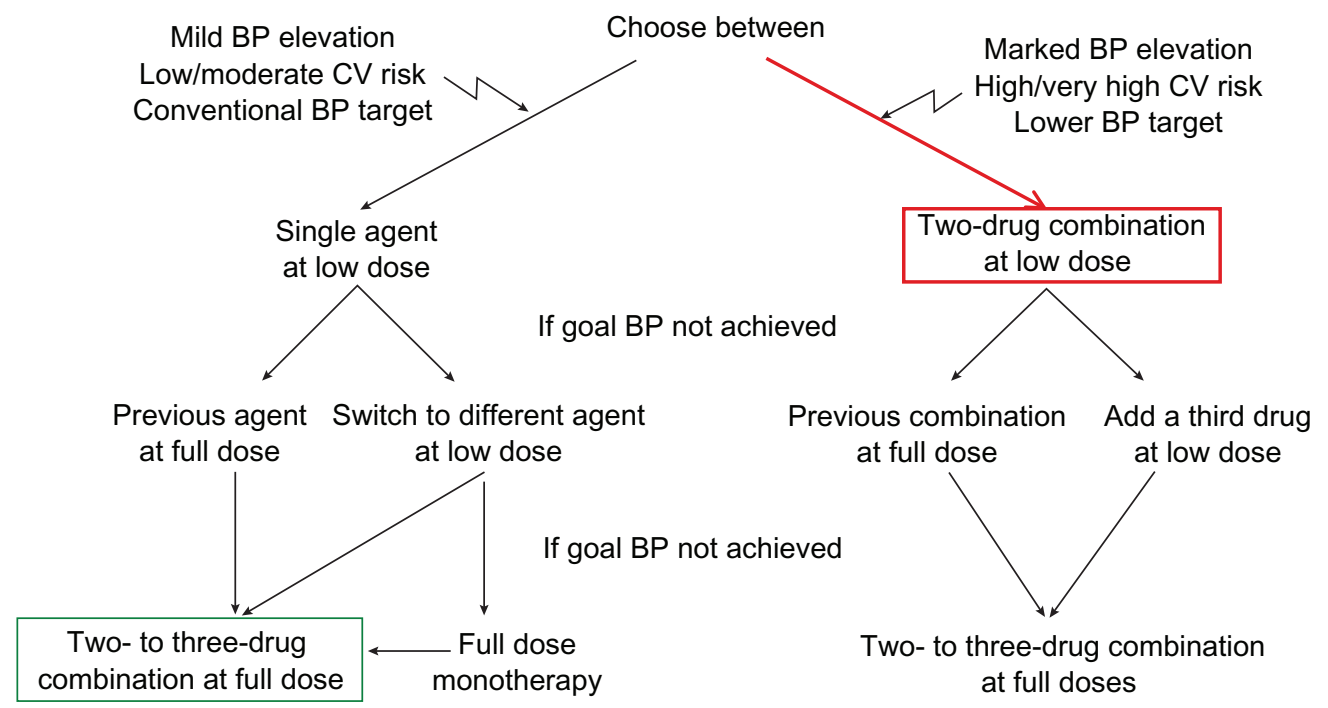

Figure 3 Combination therapy as an escalation option and as first-line therapy.

Notes: Green, 2-drug combination therapy as an option for treatment escalation; red, 2-drug combination as a first line option in patients with marked elevation of blood pressure and high cardiovascular risk.

Reproduced with permission from Mancia G, De Backer G, Dominiczak A, et al. Guidelines for the Management of Arterial Hypertension:The Task Force for the Management of Arterial Hypertension of the European Society of Hypertension (ESH) and of the European Society of Cardiology (ESC). J Hypertens. 2007; 25(6): I $05-1$ I 87. ${ }^{17}$ Copyright $(\subset)$ Lippincott Williams \& Wilkins. 


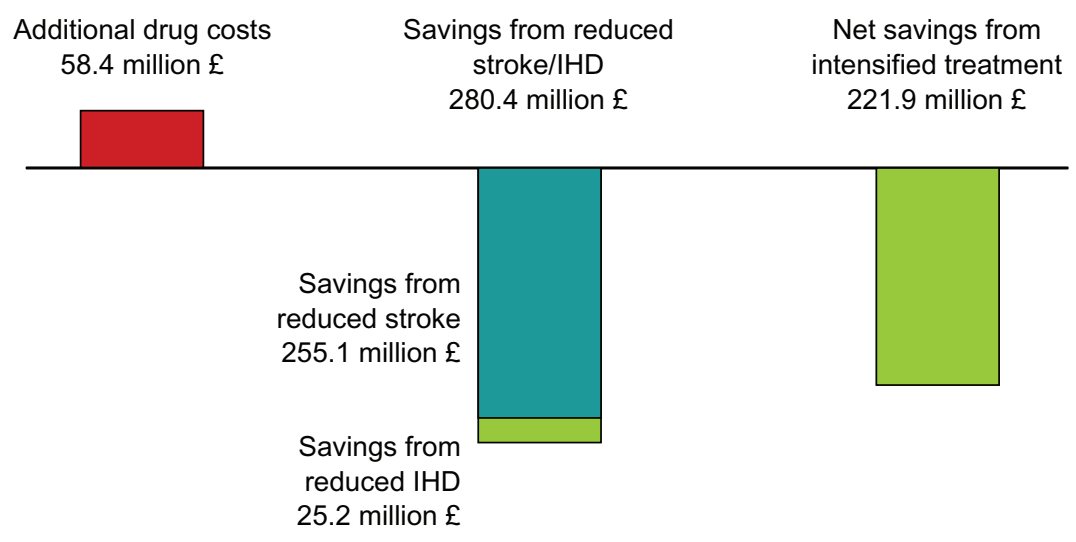

Figure 4 Cost savings in the UK by intensifying antihypertensive drug treatment. ${ }^{15}$

Notes: Optimizing antihypertensive therapy in the UK will cost $£ 58.4$ million and will prevent costs due to prevented stroke/ischemic heart disease (IHD) of $£ 280.4$ million resulting in a net benefit of $£ 221.9$ million.

most of the above-mentioned requirements for improving BP control and related morbidity on a larger scale.

\section{Candesartan}

Candesartan is an ARB that is administered orally as candesartan cilexetil; it is rapidly and completely converted to candesartan, the active compound, during absorption from the upper gastrointestinal tract. ${ }^{26}$ It is characterized by a strong binding affinity to the angiotensin II type 1 receptor and its slow dissociation. Its binding to the $\mathrm{AT}_{1}$ receptor is insurmountable, meaning that it cannot be overcome by high concentrations of angiotensin II and, under physiological conditions, may even not dissociate until the $\mathrm{AT}_{1}$ receptor is recycled. ${ }^{26}$

Twenty-four hours after administration to healthy volunteers, the angiotensin II inhibiting activity per milligram of candesartan was stronger than that shown by other ARBs. ${ }^{27}$ The trough-to-peak ratio is almost $90 \%$ (mean of all doses available). After a missed dose of candesartan, losartan, or placebo, 48-hour post-dose significant reductions of BP have been observed with candesartan $16 \mathrm{mg}$ daily but not with losartan or placebo. ${ }^{28}$

Candesartan, applied as oral monotherapy, results in a strong dose-dependent reduction of both SBP and DBP between 4 and $16 \mathrm{mg}$, levelling off at $32 \mathrm{mg}$, and reaching its maximum at 8 weeks after treatment initiation. ${ }^{29,30}$ In a direct comparison of $16 \mathrm{mg}$ candesartan and $20 \mathrm{mg}$ enalapril candesartan was significantly more effective in reducing SBP and DBP $(-13.5 /-8.7$ versus $-9.9 /-5.8 \mathrm{mmHg} ; P=0.008) .{ }^{31}$ It was also shown that $\mathrm{BP}$ returned to baseline after a missed dose of enalapril $(-7.2 /-4.5 \mathrm{mmHg})$ earlier than after a missed dose of candesartan $(-11.4 /-8.0 \mathrm{mmHg} ; P=0.0002)$. Candesartan (up to $16 \mathrm{mg}$ ) and losartan (up to $50 \mathrm{mg}$ ) were compared in an 8-week study. ${ }^{32}$ Candesartan reduced diastolic BP by 8.9 and $10.3 \mathrm{mmHg}$ with the 8 and $16 \mathrm{mg}$ doses, respectively, while the BP reduction with losartan $50 \mathrm{mg}$ was $3.7 \mathrm{mmHg}$, the latter comparison reaching statistical significance $(P=0.013)$. Twenty-four hours after the ingestion of candesartan $100 \%$ of the peak SBP/DBP lowering effect was preserved (trough/peak ratio about $100 \%$ both systolic and diastolic) while only $70 \%$ of the losartan effect was preserved (trough/peak ratio $70 \%$ both systolic and diastolic). ${ }^{32}$ These data were essentially confirmed by Lacourciere et al which also demonstrated, that after a missed dose of $16 \mathrm{mg}$ candesartan, the effect was well preserved after 36 hours, while the effect of $100 \mathrm{mg}$ losartan was significantly reduced. ${ }^{28}$

It is tempting to speculate that differences in effectiveness of these ARBs may reflect pharmacologic and pharmacokinetic differences. The elimination half-life of candesartan is longer than that of losartan and its active metabolite. Candesartan cilexetil produces clear dose-dependent antihypertensive effects, whereas it has been difficult to demonstrate this property for losartan. ${ }^{26,32}$

\section{Hydrochlorothiazide}

HCTZ mainly acts within the lumen of the distal nephron, blocking the luminal transmembrane-coupled sodium chloride transport system. The mechanism by which thiazide diuretics reduce BP is however not completely understood. It has been proposed that during long-term therapy, thiazides act by reducing total peripheral resistance probably through a direct vascular effect. ${ }^{33}$ It is important to note however that in vivo vasodilation was achieved at higher doses than those reached during long-term oral treatment. ${ }^{34} \mathrm{HCTZ}$ treatment in patients with hypertension induced changes in 
plasma volume, cardiac output, mean arterial pressure, stroke volume, heart rate, and total peripheral resistance. ${ }^{33,35}$

HCTZ has a half-life of 8 to 15 hours on chronic use and a duration of action that is slightly longer. ${ }^{36}$ HCTZ $50 \mathrm{mg}$ twice daily for 12 or 36 weeks, after a 4 -week placebo run-in period, lowered mean arterial pressure in 13 patients with untreated essential hypertension and DBP $>100 \mathrm{mmHg} .{ }^{35}$ Compared with the mean baseline value $(177.2 \mathrm{mmHg})$, these reductions were significant throughout the study duration.

\section{$\mathrm{BP}$ reduction with candesartan/HCTZ versus placebo}

Fixed dose combinations of candesartan and HCTZ are available in various doses. Candesartan $32 \mathrm{mg}$ once daily has to be regarded as a high dose (4 times standard dose). ${ }^{23}$ HCTZ 12.5 and $25 \mathrm{mg}$ have to be regarded as a half-standard and standard dose, respectively. Therefore the available combinations fulfil the requirements suggested by Law and Wald $^{23}$ for maximizing efficacy while maintaining a high tolerability.

The extent of BP reduction with candesartan/HCTZ depends on baseline BP and the dose used. A variety of combinations including $2,4,6,8,16$, or $32 \mathrm{mg}$ candesartan

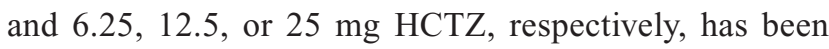
tested in clinical trials versus respective monotherapies or placebo. ${ }^{25,37-41}$ Uen et al for example demonstrated that replacing previously ineffective antihypertensive drugs by candesartan/HCTZ in patients with uncontrolled arterial hypertension significantly reduced both BP and ST-segment depression during daily life. ${ }^{41}$ Taken together these studies have consistently shown that combinations of candesartan with HCTZ, administered orally once a day for 4 to 52 weeks, induced significant reductions in SBP and DBP from baseline in patients with mild, moderate, or severe hypertension.

In a recent study by Edes et al (baseline DBP $90-114 \mathrm{mmHg}$ ), mean reductions in SBP and DBP were significantly greater with candesartan 32/HCTZ $25 \mathrm{mg}(21 / 14 \mathrm{mmHg})$ than with candesartan $32 \mathrm{mg}$ alone (13/9 mmHg), HCTZ $25 \mathrm{mg}$ alone $(12 / 8 \mathrm{mmHg})$, or placebo $(4 / 3 \mathrm{mmHg})(P<0.001$ for all comparisons). ${ }^{39}$ The proportion of patients with controlled BP (SBP $<140 \mathrm{mmHg}$ and DBP $<90 \mathrm{mmHg}$ ) at the end of this study was also significantly greater in the candesartan 32/HCTZ $25 \mathrm{mg}$ group (63\%) than in the other treatment groups ( $P<0.001$ for all comparisons).

Bönner investigated the efficacy of candesartan $32 \mathrm{mg}$ in combination with HCTZ 12.5 or $25 \mathrm{mg}$ in patients not optimally controlled using candesartan monotherapy. ${ }^{42} \mathrm{~A}$ total of 3521 patients with treated or untreated hypertension and sitting DBP of 90 to $114 \mathrm{mmHg}$ were included. After a single blind run-in phase ( 2 weeks candesartan $16 \mathrm{mg}$ followed by a 6-week treatment with candesartan $32 \mathrm{mg}) 1975$ patients who still had DBP readings of 90 to $114 \mathrm{mmHg}$ were randomized to an 8-week double-blind treatment with either candesartan $32 \mathrm{mg}$ alone or in combination with HCTZ $12.5 \mathrm{mg}$ or $25 \mathrm{mg}$ respectively. Mean BP (153/97 $\mathrm{mmHg}$ at baseline) was further reduced during the double-blind treatment phase by 6.1/5.6 $\mathrm{mmHg}$ in the candesartan monotherapy group, by 13.0/8.8 $\mathrm{mmHg}$ in the fixed combination with HCTZ $12.5 \mathrm{mg}$ group, and by $15.5 / 10.0 \mathrm{mmHg}$ in the fixed combination with HCTZ $25 \mathrm{mg}$ group $(P<0.01$ for all between treatment comparisons) (Figure 5).

Bönner et al tested the first-line use of candesartan $16 \mathrm{mg} / \mathrm{HCTZ} 12.5 \mathrm{mg}$ in 166 patients with no prior pharmacotherapy for a treatment duration of 6 weeks. ${ }^{25}$ Blood pressure was reduced by $38.1 / 29.4 \mathrm{mmHg}$ with $40 \%$ of patients achieving a normalization of BP. Tolerability was good showing that first line combination therapy is feasible and safe.

\section{$\mathrm{BP}$ reduction with candesartan/HCTZ versus losartan/HCTZ}

Ohma et al compared fixed dose combinations of candesartan 16/HCTZ $12.5 \mathrm{mg}$ and losartan 50/HCTZ $12.5 \mathrm{mg}$ in patients insufficiently controlled on previous monotherapy. ${ }^{43} \mathrm{BP}$ at randomization was $159.5 / 98.4 \mathrm{mmHg}$ and $160.5 / 98.5 \mathrm{mmHg}$, respectively. After 12 weeks there was a greater reduction of BP with candesartan/HCTZ (-19.4/-10.4) than with losartan/HCTZ (-13.7/-7.8 $\mathrm{mmHg})$, the differences being statistically significant. Twelve patients withdrew in the candesartan/HCTZ group ( 8 due to AEs), and 17 in the losartan/HCTZ group (12 AEs).

König compared candesartan/HCTZ and losartan/HCTZ in a 6-week study. ${ }^{44}$ Twenty-four-hour postdose mean seated BP was reduced by 32.2/21.1 $\mathrm{mmHg}$ (systolic/diastolic) in the candesartan/HCTZ group and 23.8/14.9 $\mathrm{mmHg}$ in the losartan/HCTZ group $(P<0.001)$. Blood pressure reductions 48 hours postdose were $25.6 / 16.4 \mathrm{mmHg}$ for candesartan/ HCTZ and 9.2/4.2 mmHg for losartan/HCTZ, with differences between treatments being highly significant in favor of candesartan/HCTZ (16.5/12.2 mmHg; $P<0.001)$. Both treatments were well tolerated.

\section{Tolerability/compliance}

ARBs are generally regarded to be a drug class with high compliance/persistence. ${ }^{45}$ Persistence with antihypertensive 


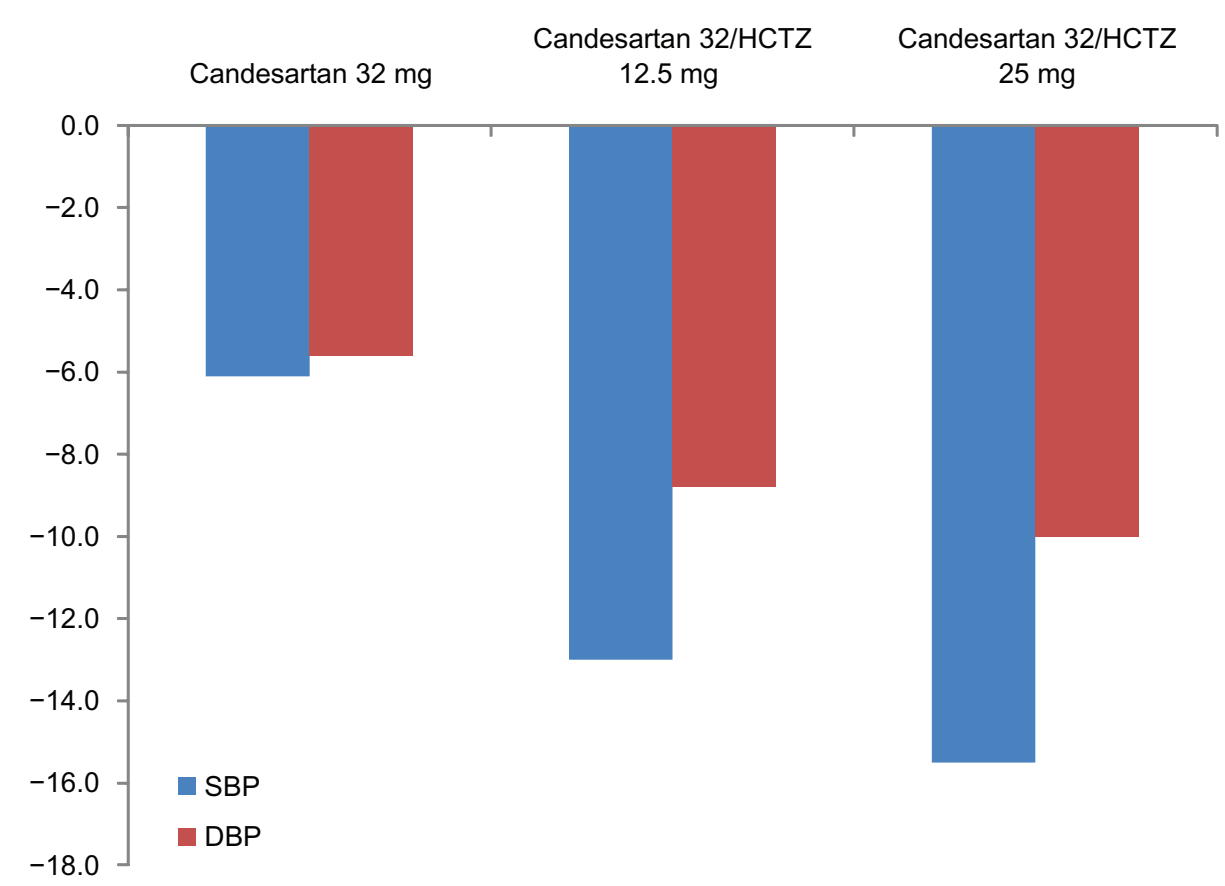

Figure 5 Blood pressure reduction with $32 \mathrm{mg}$ candesartan alone or in combination with 12.5 or 25 mg HCTZ in patients not sufficiently controlled on monotherapy. ${ }^{42}$

medication (including candesartan) was compared between different drug classes and between substances within one drug class in an Australian analysis covering the years 2004 to $2006 .{ }^{46}$ The database yielded information relating to 48,690 patients prescribed antihypertensive medication. The median persistence time was 20 months, which was also the median persistence with ARBs or ACEi. The median persistence with $\mathrm{CCBs}$ was considerably lower (median persistence time 7 months; $-57 \%, P<0.001$ ). There were further differences in persistence between individual drugs in the respective classes, the best outcomes being with candesartan and telmisartan $(10 \%-20 \%$ better than the other ARBs considered), perindopril (ACEi; 25\% better other ACEi) and lercanidipine (CCB; 25\% better than other CCBs). This high persistence was reflected in the recent DIRECT trial in that about $80 \%$ of patients were compliant with $32 \mathrm{mg}$ candesartan even when being nominally normotensive. ${ }^{47,48}$

Candesartan/HCTZ is generally well tolerated in patients with mild to moderate hypertension. Combined data from 5 randomised, double-blind, placebo-controlled clinical trials indicated that AEs during candesartan/HCTZ therapy (up to $16 \mathrm{mg} / 25 \mathrm{mg}$ once daily) are uncommon and only few were serious. ${ }^{49}$ Among patients receiving candesartan/HCTZ or placebo the incidence of serious AEs was 1.6 and $2.1 \%$, respectively, while 3.3 and $2.7 \%$ of patients discontinued treatment because of AEs. The most common AEs were headache, back pain, dizziness, and respiratory infections.

Recent trials indicated that the AE profile of candesartan $32 \mathrm{mg}$ in combination with 12.5 or $25 \mathrm{mg} \mathrm{HCTZ}$ is comparable to the aforementioned observations. ${ }^{39,42}$ Bönner et al reported about $1 \%$ serious AEs that were independent of whether monotherapy with candesartan or combination therapy including HCTZ was considered. For metabolic parameters, a slight increase of serum ureate and serum creatinine was observed with the fixed combinations while other parameters were essentially unchanged (Table 2). ${ }^{42}$ Edes et al reported a rate of serious $\mathrm{AE}$ for the fixed dose combination that was even lower compared to placebo $(0.2 \%$ versus $3.1 \%)$, with overall $\mathrm{AE}$ rate ranging between $23 \%$ and $25 \%$ for placebo, HCTZ, candesartan, and their combination. ${ }^{39}$

Mengden et al compared drug regimen compliance (DRC) with antihypertensive combination therapy in patients whose BP was controlled versus uncontrolled after 4 weeks of self-monitored BP measurement. ${ }^{50}$ Whether switching one drug of the combination therapy to candesartan/HCTZ $(16 \mathrm{mg} / 12.5 \mathrm{mg})$ in uncontrolled patients with and without compliance intervention program would improve BP normalization was also evaluated. It was found that normalization of BP was associated with superior drug regimen compliance in previously uncontrolled patients treated with a combination drug regimen. Switching still-uncontrolled patients to 
Table 2 Laboratory values at baseline, and mean change $( \pm S D)$ from baseline ${ }^{a}$ after 8 weeks of treatment ${ }^{42}$

\begin{tabular}{|c|c|c|c|}
\hline & $\begin{array}{l}\text { Candesartan } 32 \mathrm{mg} \\
\mathrm{n}=653\end{array}$ & $\begin{array}{l}\text { Candesartan } 32 \mathrm{mg} \\
\text { I } 2.5 \mathrm{mg} \mathrm{HCTZ} \\
\mathrm{n}=654\end{array}$ & $\begin{array}{l}\text { Candesartan } 32 \mathrm{mg} \\
25 \mathrm{mg} \text { HCTZ } \\
\mathrm{n}=664\end{array}$ \\
\hline \multicolumn{4}{|c|}{ S-urate $(\mu \mathrm{mol} / \mathrm{L})$} \\
\hline Baseline & $334.5(84.6)$ & $335.2(82.6)$ & $339.1(80.6)$ \\
\hline Change & $5.1(52.0)$ & $27.4(52.3)$ & $43.9(57.8)$ \\
\hline \multicolumn{4}{|c|}{ S-potassium (mmol/L) } \\
\hline Baseline & $4.5(0.4)$ & $4.5(0.4)$ & $4.5(0.4)$ \\
\hline Change & $0.0(0.4)$ & $0.1(0.4)$ & $-0.1(0.4)$ \\
\hline \multicolumn{4}{|c|}{ S-glucose (mmol/L) } \\
\hline Baseline & $6.0(1.4)$ & $6.2(1.9)$ & $5.9(1.5)$ \\
\hline Change & $0.0(1.0)$ & $0.4(1.0)$ & $0.0(0.9)$ \\
\hline \multicolumn{4}{|c|}{ S-triglycerides $(\mathrm{mmol} / \mathrm{l})$} \\
\hline Baseline & $2.0(1.4)$ & $1.9(1.8)$ & $2.0(\mathrm{I} .5)$ \\
\hline Change & $0.0(1.2)$ & $0.0(1.6)$ & $0.2(2.2)$ \\
\hline \multicolumn{4}{|c|}{ S-cholesterol (mmol/L) } \\
\hline Baseline & $5.8(I . I)$ & $5.8(I . I)$ & $5.9(1.0)$ \\
\hline Change & $0.1(0.7)$ & $0.0(0.8)$ & $0.1(0.8)$ \\
\hline \multicolumn{4}{|c|}{ S-creatinine $(\mu \mathrm{mol} / \mathrm{L})$} \\
\hline Baseline & $79.8(15.8)$ & $79.9(14.8)$ & $80.3(15.4)$ \\
\hline Change & $0.0(10.5)$ & I.8 (9.8) & $4.5(13.1)$ \\
\hline
\end{tabular}

aBaseline: after a run-in phase with $16 \mathrm{mg}$ candesartan for 2 weeks and $32 \mathrm{mg}$ candesartan for 6 weeks.

candesartan/HCTZ significantly improved BP control and stabilized a declining DRC.

\section{Patient types}

\section{Patients with heart failure}

Heart failure is a frequent comorbidity in patients with hypertension. It is characterized by a decline in systolic or diastolic function, the latter being a typical complication of long-term uncontrolled hypertension. The fixed dose combination of candesartan/HCTZ has never been formally tested in this patient population, but the benefits of blocking the RAS and enhancing diuresis are basic concepts in the treatment of HF. ${ }^{51} \mathrm{HCTZ}$ is recommended for the treatment of patients with $\mathrm{HF}$ in doses of $25 \mathrm{mg}$ to initiate treatment and maintenance doses of between 2.5 and $100 \mathrm{mg}$ daily. ${ }^{51}$ Candesartan is recommended to be started at a dose of 4 or $8 \mathrm{mg}$ daily and uptitrated to a target dose of $32 \mathrm{mg}$.

The basis for the recommendation of candesartan was the results of the CHARM trial program. ${ }^{52}$ In CHARM candesartan was tested in patients with systolic HF given either on top of an $\mathrm{ACEi}^{53}$ or in cases of ACEi intolerance. ${ }^{54}$ A third trial investigated the effect of candesartan in diastolic HF (HF with preserved systolic function). ${ }^{55}$ Overall, 7601 patients were randomly assigned candesartan (titrated to
$32 \mathrm{mg}$ once daily) or matching placebo, and followed up for at least 2 years. In the overall CHARM trial program $82.8 \%$ of patients in the candesartan arm and $82.6 \%$ of patients in the placebo arm received diuretics and a further 16.9 and $16.6 \%$ respectively spironolactone.

In CHARM Alternative (candesartan given instead of an ACEi) treatment resulted in a relative risk reduction (RRR) of death from cardiovascular cause or hospital admission for worsening HF of 23\% (ARR 7\%, NNT 14, over 34 months of follow-up, adjusted $P<0.0001$ (Figure 6). ${ }^{54}$ In the CHARM Added trial (candesartan on top of existing ACEi therapy) candesartan cotreatment resulted in a $15 \%$ RRR of cardiovascular death or hospital admission for CHF (ARR 4\%, NNT 25, over 41 months of follow-up, adjusted $P=0.010) .{ }^{54}$ The CHARM Preserved trial (candesartan in patients with HF but preserved systolic function) candesartan did not show a significant reduction in the risk of the primary composite endpoint (adjudicated death from cardiovascular causes or admission with HF) but did show a significant reduction in the number of patients admitted to hospital with CHF (ARR 3.3\%, NNT 30, over 37 months follow up, $P=0.017){ }^{55}$

In summary it appears possible to initiate drug treatment of HF with both combination agents at low dose, uptitrate 


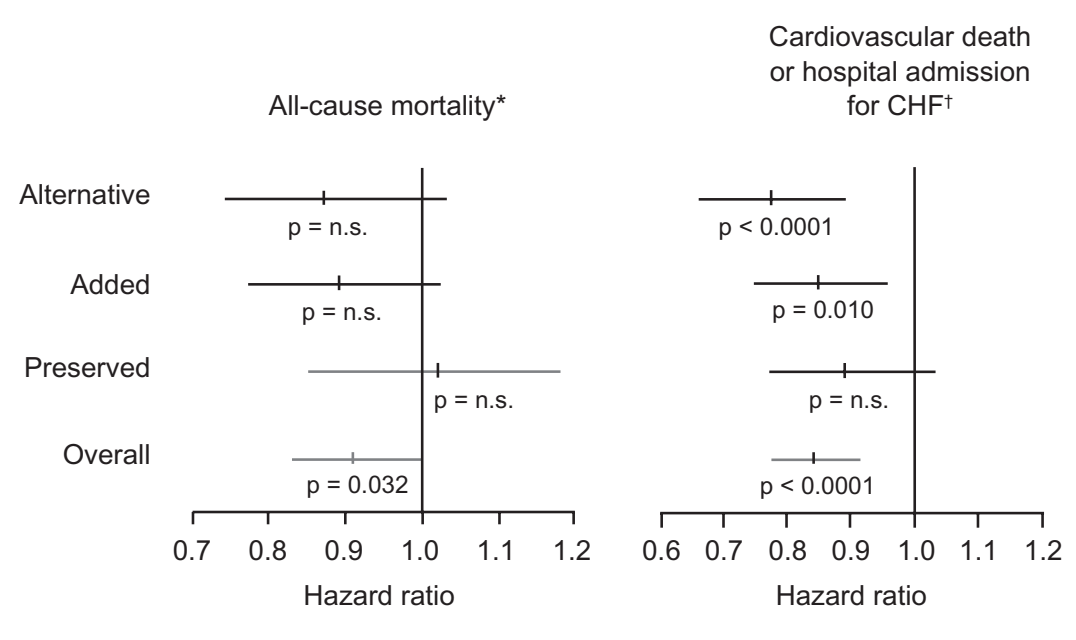

Figure 6 Results of the CHARM trial program. ${ }^{52-55}$

Notes: ${ }^{*} p$ for heterogeneity $0.37 ;{ }^{\dagger} p$ for heterogeneity 0.33 .

Reprinted from Pfeffer MA, Swedberg K, Granger CB, et al. Effects of candesartan on mortality and morbidity in patients with chronic heart failure: the CHARM-Overall programme. The Lancet. 362:759-766. ${ }^{52}$ Copyright (C) 2003, with permission from Elsevier.

candesartan and HCTZ as warranted and, should the doses fit, switch to a fixed dose combination of candesartan 32/HCTZ $25 \mathrm{mg}$ for maintenance treatment.

\section{Patients with stroke}

Stroke is a frequent, serious, and finally costly complication of hypertension. Candesartan was tested in 2 trials with respect to this indication, one testing the capability of preventing stroke or related disabilities (SCOPE, ${ }^{56}$ see section Elderly patients), the other testing cerebro- and cardiovascular endpoints in patients with a history of stroke (ACCESS). ${ }^{57}$

ACCESS was designed to evaluate the safety of early antihypertensive treatment in patients with acute cerebral ischemia). ${ }^{57}$ Patients with motor paresis and initial $\mathrm{SBP}>200 \mathrm{mmHg}$ and/or DBP $>110 \mathrm{mmHg}$ or mean BP of 2 measurements $>180 \mathrm{mmHg}$ and/or $105 \mathrm{mmHg}$, respectively, were included. The trial was stopped prematurely after the recruitment of 349 patients due to an imbalance in endpoints. Cumulative 12-month mortality and the number of vascular events differed significantly in favor of the candesartan group (OR 0.475; 95\% CI 0.252-0.895). There were no cardiovascular or cerebrovascular events as a result of hypotension. Treatment was started with $4 \mathrm{mg}$ candesartan daily on day 1 . On day 2 , dosage was increased to 8 or $16 \mathrm{mg}$ candesartan if $\mathrm{BP}$ exceeded $160 \mathrm{mmHg}$ systolic or $100 \mathrm{mmHg}$ diastolic. In patients in the candesartan group who were still hypertensive on day 7 (mean daytime $\mathrm{BP}>135 / 85 \mathrm{mmHg}$ ), candesartan was increased or an additional antihypertensive drug (HCTZ, felodipine, metoprolol) was added. The control group received placebo for the first 7 days and 8 to $16 \mathrm{mg}$ candesartan throughout the rest of the study.

In the ongoing SCAST trial (NCT00120003) candesartan is tested in patients with stroke (ischemic or hemorrhagic) and SBP $\geq 140 \mathrm{mmHg}$. Patients receive $4 \mathrm{mg}$ candesartan on day $1 ; 8 \mathrm{mg}$ on day $2 ; 16 \mathrm{mg}$ on days 3 to 7 . Dose adjustment in cases of SBP $<120 \mathrm{mmHg}$, or symptomatic fall in BP are mandated. From day 8 therapies can be supplemented with any antihypertensive agent including diuretics.

Taken together there is good evidence that early candesartan treatment after acute stroke might be able to prevent vascular events and mortality. The fixed dose combination might be useful after several days of candesartan monotherapy uptitration after which HCTZ in low dose is added to maintain or achieve BP control.

\section{Patients with diabetes mellitus}

Antihypertensive treatment in diabetic patients is complicated by the fact that baseline BP readings are usually high, while having to meet lower BP goals $(<130 / 80 \mathrm{mmHg}$ in most cases). ${ }^{17}$ ARBs are beneficial within the context of diabetes because they have been shown to delay the development of diabetes more than any other drug class (Figure 7) ) $^{58,59}$ and to be at least neutral or even beneficial with respect to metabolic parameters. As has been shown in a number of clinical trials, the reduction of cardiovascular morbidity following antihypertensive treatment is usually, but not always, pronounced in patients with diabetes. ${ }^{60,61}$

Candesartan reduced the number of patients developing diabetes in the CHARM, ${ }^{62}$ SCOPE,${ }^{63}$ and ALPINE trials. ${ }^{64}$ When administered to a group of hypertensive subjects it 
Treatment

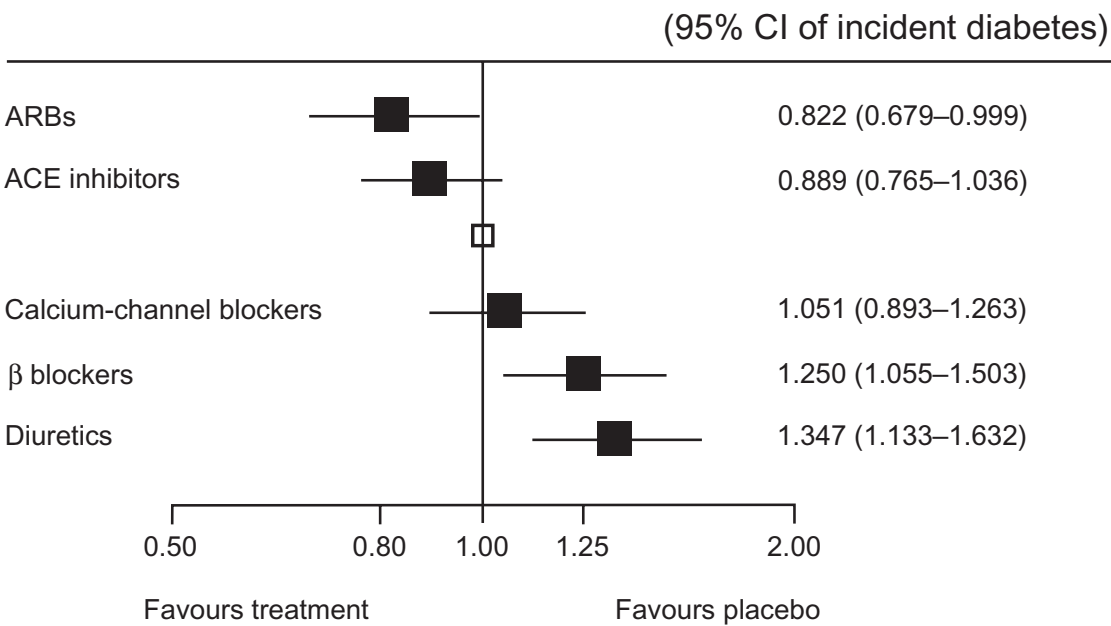

Figure 7 Development of diabetes - results of a meta-analysis.

Reprinted from Lam SK, Owen A. Incident diabetes in clinical trials of antihypertensive drugs. The Lancet. 369:I5I3-15।4. ${ }^{59}$ Copyright @ 2007, with permission from Elsevier.

reduced C-reactive protein and increased adiponectin and markers of insulin sensitivity, as measured by QUICKI (Quantitative Insulin-Sensitivity Check Index). ${ }^{65}$

It also reduced BP effectively in diabetic patients. ${ }^{66}$ Bramlage et al demonstrated in an observational study in primary care that candesartan 16/HCTZ $12.5 \mathrm{mg}$ lowered BP effectively in patients with and without diabetes. ${ }^{45}$ The absolute amount of BP lowering (-27.2/-1-3.4 mmHg) appeared to be dependent on baseline BP but did not differ among patient types (diabetes, metabolic syndrome, or neither condition).

Microalbuminuria in diabetes is strongly predictive of nephropathy, end-stage renal disease, and premature cardiovascular morbidity and mortality. Effective preventive therapies are therefore a clinical priority. The effect of candesartan in the prevention of microalbuminuria was tested in a pooled analysis of the DIRECT trial program in which normotensive patients with type $1(\mathrm{n}=3326)$ and $2(n=1905)$ diabetes were included. ${ }^{67}$ Due to the study design the incidence of microalbuminuria was low in this analysis and no differences in the risk for albuminuria were noted (HR 0.95; 95\% CI 0.78-1.16). Pooled results showed that the annual rate of change in albuminuria was $5.53 \%$ lower (CI, $0.73 \%-10.14 \% ; P=0.024)$ with candesartan than with placebo. Studies conducted by Trenkwalder ${ }^{68}$ and Mogensen ${ }^{69}$ have however shown that candesartan is effective in lowering the level of albumin excretion in patients with hypertension, diabetes, and already existing microalbuminuria. Taking a much higher than recommended dose of the hypertension drug candesartan was shown to effectively lower the amount of protein excreted in the urine of patients with kidney disease in a study by Burgess et al. ${ }^{70} 269$ patients with persistent proteinuria despite treatment with $16 \mathrm{mg}$ candesartan were randomized to receive 16,64 , or $128 \mathrm{mg}$ daily of candesartan for 30 weeks. It was found that patients taking $128 \mathrm{mg}$ of candesartan experienced a $33 \%$ reduction in proteinuria compared with those receiving $16 \mathrm{mg}$ candesartan by the end of the study. There is however a missing link between microalbuminuria reduction and morbidity and mortality endpoints which have so far been reported only from post-hoc analyses. A respective study is however already underway to provide this link. ${ }^{71}$ Important in this respect are the results of the GUARD study that combined an ACEi with either amlodipine or HCTZ and demonstrated that with HCTZ the nephroprotective effect of benazepril was preserved while it was reduced when amlodipine was chosen as the combination partner. ${ }^{72}$

The DIRECT trial program was a series of clinical trials investigating the effect of candesartan on the development and progression diabetic retinopathy who were either normotensive or had treated hypertension. ${ }^{47,73}$ DIRECT consisted of three randomized, double-blind, placebocontrolled multicenter studies designed to investigate the potential for candesartan in halting the progression of, and possibly prevent, diabetic retinopathy. Results showed that candesartan was beneficial for patients with type 2 diabetes who had established mild to moderate retinopathy, because candesartan had an additional, BP-independent effect on improvement of retinopathy (Figure 8). Candesartan was also shown to be indicated for patients with type 1 diabetes 


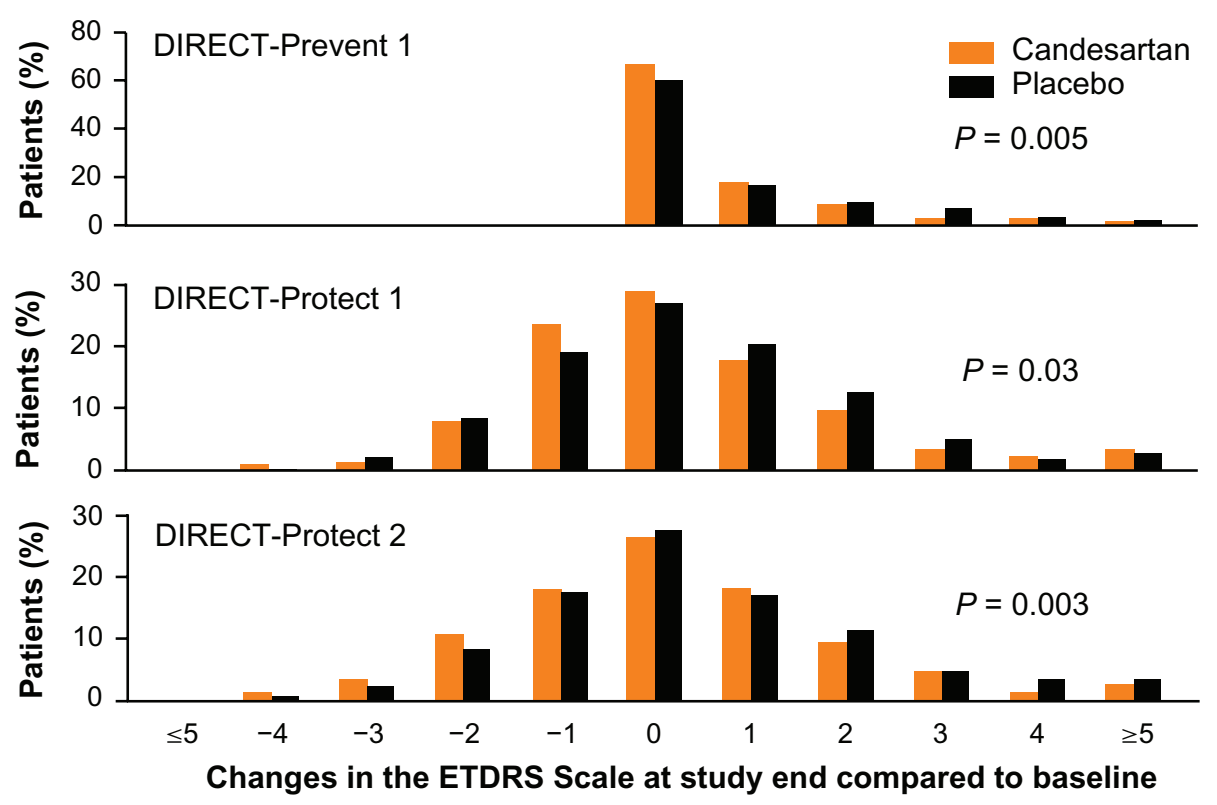

Figure 8 Results of the DIRECT trial program. ${ }^{47,73}$

without retinopathy, in order to reduce their risk of developing retinopathy.

In summary there is an abundance of evidence for the use of candesartan in patients with diabetes or a high risk for developing such. Data on the use of a fixed dose combination of candesartan/HCTZ are scarce, leaving it unproven that a combination treatment is likewise beneficial. Data addressing the dysmetabolic potential have however shown that the metabolic profile of HCTZ is neutralized when adding candesartan. Because of the need for multiple drug-drug combinations there is a clear need for combination therapy including diuretics, which are favored in common co-morbidities of diabetes, eg, CHF or diabetic nephropathy.

\section{Elderly patients}

The pharmacokinetics of candesartan were investigated after single and repeated once-daily doses in a trial by Hübner et a $1^{74}$ of candesartan in the dose range 2 to $16 \mathrm{mg}$ in both younger (19-40 years) and elderly (65-78 years) healthy volunteers. The area under the curve (AUC) and maximal concentration $\left(\mathrm{C}_{\max }\right)$ of candesartan showed dose-proportional increases in the dose range of 2 to $16 \mathrm{mg}$ candesartan after both single and repeated once-daily tablet intake, indicating linear pharmacokinetics in both younger and elderly healthy subjects. The time to peak candesartan concentrations after tablet intake was consistently approximately 4 hour at all dose levels. Only mild AEs were recorded, with 'headache' the most commonly reported event, and no increase in the number of reported AEs was observed with higher doses of candesartan cilexetil. ${ }^{74}$
Results of the SCOPE study implied that candesartan treatment reduces cardiovascular morbidity and mortality in old and very old patients with mild to moderate hypertension. ${ }^{75,76}$ Candesartan-based antihypertensive treatment may also have positive effects on cognitive function and quality of life. SCOPE was a multi-center, prospective, randomized, double-blind, parallel-group study. The primary objective was to assess the effect of candesartan $8-16 \mathrm{mg}$ once daily, on major cardiovascular events in elderly patients (70-89 years of age) with mild hypertension (DBP 90-99 and/or SBP 160-179 mmHg). The main analysis showed that non-fatal stroke was reduced by $28 \%(P=0.04)$ in the candesartan group compared with the control group, and there was a non-significant $11 \%$ reduction in the primary endpoint, major cardiovascular events $(P=0.19)$. Significant risk reductions with candesartan in major cardiovascular events (32\%, $P=0.013)$, cardiovascular mortality $(29 \%, P=0.049)$ and total mortality $(27 \%, P=0.018)$ were observed in patients who did not receive add-on therapy after randomization, and in whom the difference in BP was 4.7/2.6 mmHg. Other analyzes suggest positive effects of candesartan-based treatment on cognitive function, quality of life and new-onset diabetes. Results of SCOPE strongly suggested that candesartan treatment reduces cardiovascular morbidity and mortality in old and very old patients with mild to moderate hypertension. Candesartan-based antihypertensive treatment may also have positive effects on cognitive function and quality of life. ${ }^{76}$

Subgroup analyses from the CHARM study in patients with HF showed that older patients were at a greater absolute 
risk of adverse CV mortality and morbidity outcomes, but derived a similar RRR and, therefore, a greater absolute benefit from treatment with candesartan, despite receiving a somewhat lower mean daily dose of candesartan. ${ }^{77}$ Adverse effects were more common with candesartan than with placebo, although the relative risk of adverse effects was similar across age groups. The benefit to risk ratio for candesartan was thus favorable across all age groups.

In summary, given that diuretics are frequently indicated in elderly patients there appears to be a role for fixed dose combinations of candesartan/HCTZ. But again evidence has been acquired with free combinations of candesartan with other antihypertensive drugs including thiazide diuretics.

\section{Economic evaluation}

The addition of candesartan to standard therapy for CHF provided important clinical benefits at little or no additional cost in France, Germany, and the UK, according to a detailed economic analysis focusing on major cardiovascular events and prospectively collected resource-use data from the CHARMAdded and CHARM-Alternative trials in patients with $\mathrm{CHF}$ and left ventricular (LV) systolic dysfunction. ${ }^{78}$ Results of a corresponding cost-effectiveness analysis showed that candesartan was either dominant over placebo or was associated with small incremental costs per life-year gained, depending on the country and whether individual trial or pooled data were used. Preliminary data from a US cost-effectiveness analysis based on CHARM data also showed favorable results for candesartan cilexetil. Two cost-effectiveness analyses of candesartan cilexetil in hypertension have been published, both conducted in Sweden.

Data from the SCOPE trial in elderly patients with hypertension, which showed a significant reduction in non-fatal stroke with candesartan-based therapy versus non-candesartan based treatment, were incorporated into a Markov model and an incremental cost-effectiveness ratio of $€ 12,824$ per QALY gained was calculated (2001 value).

In conclusion, despite some inherent limitations, economic analyses incorporating CHARM data and conducted primarily in Europe have shown that candesartan cilexetil appears to be cost-effective when added to standard CHF treatment in patients with CHF and compromised LV systolic function. The use of candesartan cilexetil as part of antihypertensive therapy in elderly patients with elevated BP was also deemed to be cost effective in a Swedish analysis, primarily resulting from a reduced risk of non-fatal stroke (as shown in the SCOPE study); however, the generalizability of results to other contexts has not been established. Cost-effectiveness analyses comparing candesartan cilexetil with ACE inhibitors or other angiotensin receptor blockers in CHF or hypertension are lacking, and results reported for candesartan cilexetil in a Swedish economic analysis of ALPINE data focusing on outcomes for diabetes require confirmation and extension.

\section{Conclusions}

The fixed dose combination of candesartan and HCTZ is a valuable addition to the armamentarium of drugs in the treatment of hypertension, because of its high efficacy in reducing $\mathrm{BP}$, its tolerability, and the high compliance of patients with treatment. Comparative studies with losartan/ HCTZ have consistently shown a higher clinical efficacy with the candesartan/HCTZ combination. Candesartan/HCTZ therefore assists both physicians and patients in achieving long-term treatment goals.

Data on the reduction of cardiovascular endpoints with fixed dose combinations of antihypertensive drugs are scarce, as are the data for candesartan/HCTZ. However many trials have tested candesartan versus a non-RAS blocking comparator based on a standard therapy including thiazide diuretics. The indications tested were HF and stroke, and particular emphasis was put on elderly patients or those with diabetes. In patients with HF, for example, the fixed dose combination might be applied in patients in whom individual titration resulted in a dose of $32 \mathrm{mg}$ candesartan and $25 \mathrm{mg} \mathrm{HCTZ}$ which can then be combined into one tablet to increase compliance with treatment. Also in patients with stroke the fixed dose combination might be used in patients in whom maintenance therapy with both components is considered.

\section{Abbreviations}

ACCESS, The Acute Candesartan Cilexetil Therapy in Stroke Survivors; ACCOMPLISH, Avoiding Cardiovascular Events in Combination Therapy in Patients Living with Systolic Hypertension; ACEi, ACE inhibitor; AE, adverse event; ALPINE, Antihypertensive treatment and Lipid Profile In a North of Sweden Efficacy Evaluation; $\mathrm{ARB}$, angiotensin receptor blocker; ARR, absolute risk reduction; AT, angiotensin; AUC, area under the curve; BP, blood pressure; CANDIA, CANdesartan and DIuretic vs Amlodipine in hypertensive patients; $\mathrm{CCB}$, calcium channel blocker; CHARM, Candesartan in Heart FailureAssessment of Reduction in mortality and Morbidity; CHD, coronary heart disease; $\mathrm{CHF}$, chronic heart failure; $\mathrm{CI}$, confidence interval; CV, cardiovascular; DBP, diastolic blood pressure; DDD, defined daily doses; DIRECT, The 
DIabetic REtinopathy Candesartan Trials; DRC, drug regimen compliance; ESC, European Society of Cardiology; ESH, European Society of Hypertension; HCTZ, hydrochlorothiazide; HDL, high-density lipoprotein; HF, heart failure; HR, hazard ratio; JNC, Joint National Committee; LIFE, Losartan Intervention For Endpoint reduction in hypertension; LV, left ventricular; MOSES, Morbidity and Mortality after Stroke - Eprosartan vs Nitrendipine for Secondary Prevention; NHS, National Health Service (UK); NICE, National Institutes of Clinical Excellence; NNT, number needed to treat; OR, odds ratio; QUICKI, Quantitative Insulin-Sensitivity Check Index; PRA, plasma renin activity; QALY, quality adjusted life year; RAS, renin-angiotensin system; RRR, relative risk reduction; SBP, diastolic blood pressure; SCAST, Scandinavian Candesartan Acute Stroke Trial; SCOPE, Study on COgnition and Prognosis in the Elderly; UK, United Kingdom; US, United States.

\section{Acknowledgements}

The preparation of this manuscript has been financially supported by Takeda Pharma, Aachen, Germany. Takeda had no role in outlining, editing or determining the final content of this review. This was left at the discretion of the authors who take full responsibility for its content.

\section{Disclosures}

TM, SU and PB disclose receipt of lecture honoraries and research support from Takeda Pharma, Aachen, Germany.

\section{References}

1. WHO 2002. 2009

2. Mancia G, De BG, Dominiczak A, et al. Guidelines for the management of arterial hypertension: The Task Force for the Management of Arterial Hypertension of the European Society of Hypertension (ESH) and of the European Society of Cardiology (ESC). Eur Heart J. 2007;28(12):1462-1536.

3. Lewington S, Clarke R, Qizilbash N, Peto R, Collins R. Age-specific relevance of usual blood pressure to vascular mortality: a meta-analysis of individual data for one million adults in 61 prospective studies. Lancet. 2002;360(9349):1903-1913.

4. Kearney PM, Whelton M, Reynolds K, Muntner P, Whelton PK, He J. Global burden of hypertension: analysis of worldwide data. Lancet. 2005;365(9455):217-223.

5. Wolf-Maier K, Cooper RS, Kramer H, et al. Hypertension treatment and control in five European countries, Canada, and the United States. Hypertension. 2004;43(1):10-17.

6. Eisen SA, Miller DK, Woodward RS, Spitznagel E, Przybeck TR. The effect of prescribed daily dose frequency on patient medication compliance. Arch Intern Med. 1990;150(9):1881-1884.

7. Leenen FH, Wilson TW, Bolli P, et al. Patterns of compliance with once versus twice daily antihypertensive drug therapy in primary care: a randomized clinical trial using electronic monitoring. Can J Cardiol. 1997;13(10):914-920.

8. Fincke BG, Miller DR, Spiro A, III. The interaction of patient perception of overmedication with drug compliance and side effects. J Gen Intern Med. 1998;13(3):182-185.
9. Miller NH, Hill M, Kottke T, Ockene IS. The multilevel compliance challenge: recommendations for a call to action. A statement for healthcare professionals. Circulation. 1997;95(4):1085-1090.

10. Berlowitz DR, Ash AS, Hickey EC, et al. Inadequate management of blood pressure in a hypertensive population. N Engl J Med. 1998; 339(27):1957-1963.

11. Oliveria SA, Lapuerta P, McCarthy BD, L'Italien GJ, Berlowitz DR, Asch SM. Physician-related barriers to the effective management of uncontrolled hypertension. Arch Intern Med. 2002;162(4):413-420.

12. Hyman DJ, Pavlik VN. Self-reported hypertension treatment practices among primary care physicians: blood pressure thresholds, drug choices, and the role of guidelines and evidence-based medicine. Arch Intern Med. 2000;160(15):2281-2286.

13. Alderman M. World Health Organization - International Society of Hypertension Guideliines for the Management of Hypertension. Beal AK, editor. Blood Press. 1999;8(Suppl 1):9-43.

14. Julius S. Worldwide trends and shortcomings in the treatment of hypertension. Am J Hypertens. 2000;13(5 Pt 2):57S-61S.

15. NICE costing report. URL: http://www.nice.org.uk/nicemedia/pdf/ CG034costingreport.pdf. 2002.

16. Pittrow D, Kirch W, Bramlage P, et al. Patterns of antihypertensive drug utilization in primary care. Eur J Clin Pharmacol. 2004;60(2):135-142.

17. Mancia G, De Backer G, Dominiczak A, et al. Guidelines for the Management of Arterial Hypertension: The Task Force for the Management of Arterial Hypertension of the European Society of Hypertension (ESH) and of the European Society of Cardiology (ESC). J Hypertens. 2007;25(6):1105-1187.

18. Chobanian AV, Bakris GL, Black HR, et al. The Seventh Report of the Joint National Committee on Prevention, Detection, Evaluation, and Treatment of High Blood Pressure: The JNC 7 Report. JAMA. 2003; 289(19):2560-2571.

19. Stolk P, Van Wijk BL, Leufkens HG, Heerdink ER. Between-country variation in the utilization of antihypertensive agents: guidelines and clinical practice. J Hum Hypertens. 2006;20(12):917-922.

20. Jamerson K, Weber MA, Bakris GL, et al. Benazepril plus amlodipine or hydrochlorothiazide for hypertension in high-risk patients. $N$ Engl $J$ Med. 2008;359(23):2417-2428.

21. Jamerson KA, Bakris GL, Wun CC, et al. Rationale and design of the avoiding cardiovascular events through combination therapy in patients living with systolic hypertension (ACCOMPLISH) trial: the first randomized controlled trial to compare the clinical outcome effects of first-line combination therapies in hypertension. Am J Hypertens. 2004;17(9):793-801.

22. Bramlage P. Fixed-dose combinations of renin-angiotensin blocking agents with calcium channel blockers or hydrochlorothiazide in the treatment of hypertension. Exp Opin Pharmacother. 2009;10(11): $1755-1767$.

23. Law MR, Wald NJ, Morris JK, Jordan RE. Value of low dose combination treatment with blood pressure lowering drugs: analysis of 354 randomised trials. BMJ. 2003;326(7404):1427-1431.

24. Franklin SS, Neutel JM, Donovan M, Bouzamondo H. Irbesartan/ hydrochlorothiazide as initial therapy: subanalysis in patients with systolic BP > $180 \mathrm{mmHg}$ and diastolic $\mathrm{BP}>110 \mathrm{mmHg}$, efficacy and safety. J Hypertens. 2008;(Suppl 1):S159.

25. Bönner G, Fuchs W. Fixed combination of candesartan with hydrochlorothiazide in patients with severe primary hypertension. Curr Med Res Opin. 2004;20(5):597-602.

26. Oparil S. Newly emerging pharmacologic differences in angiotensin II receptor blockers. Am J Hypertens. 2000;13(1 Pt 2):18S-24S.

27. Fuchs B, Breithaupt-Grogler K, Belz GG, et al. Comparative pharmacodynamics and pharmacokinetics of candesartan and losartan in man. J Pharm Pharmacol. 2000;52(9):1075-1083.

28. Lacourciere Y, Asmar R. A comparison of the efficacy and duration of action of candesartan cilexetil and losartan as assessed by clinic and ambulatory blood pressure after a missed dose, in truly hypertensive patients: a placebo-controlled, forced titration study. Candesartan/ Losartan study investigators. Am J Hypertens. 1999;12(12 Pt 1-2): $1181-1187$. 
29. Sever P, Michel J, Voet B. Candesartan cilexitil (CC): A meta-analysis of time-to-effect relationship. Am J Hypertens. 1998;11(4 Pt 2):79A.

30. Elmfeldt D, Olofsson B, Meredith P. The relationships between dose and antihypertensive effect of four AT1-receptor blockers. Differences in potency and efficacy. Blood Press. 2002;11(5):293-301.

31. Himmelmann A, Keinanen-Kiukaanniemi S, Wester A, Redon J, Asmar R, Hedner T. The effect duration of candesartan cilexetil once daily, in comparison with enalapril once daily, in patients with mild to moderate hypertension. Blood Press. 2001;10(1):43-51.

32. Andersson OK, Neldam S. A comparison of the antihypertensive effects of candesartan cilexetil and losartan in patients with mild to moderate hypertension. J Hum Hypertens. 1997;11(Suppl 2):S63-S64.

33. Conway J, Lauwers P. Hemodynamic and hypotensive effects of longterm therapy with chlorothiazide. Circulation. 1960;21:21-27.

34. Pickkers P, Hughes AD, Russel FG, Thien T, Smits P. Thiazide-induced vasodilation in humans is mediated by potassium channel activation. Hypertension. 1998;32(6):1071-1076.

35. van Brummelen P, Man int Veld AJ, Schalekamp MA. Hemodynamic changes during long-term thiazide treatment of essential hypertension in responders and nonresponders. Clin Pharmacol Ther. 1980;27(3):328-336.

36. Carter BL, Ernst ME, Cohen JD. Hydrochlorothiazide versus chlorthalidone: evidence supporting their interchangeability. Hypertension. 2004;43(1):4-9.

37. Azizi M, Nisse-Durgeat $\mathrm{S}$, French Collaborative Group. Comparison of the antihypertensive effects of the candesartan $8 \mathrm{mg}$ hydrochlorothiazide $12.5 \mathrm{mg}$ combination vs the valsartan $80 \mathrm{mg}$ hydrochlorothiazide $12.5 \mathrm{mg}$ combination in patients with essential hypertension resistant to monotherapy. [abstract no. P2.367]. J Hypertens. 2004;22(Suppl 2): S254-S255.

38. Oparil S, Michelson EL. Long term efficacy, safety, and tolerability of candesartan cilexitil added to hydrochlorothiazide in patients with severe hypertension. Am J Hypertens. 2009;12:120.

39. Edes I. Combination therapy with candesartan cilexetil $32 \mathrm{mg}$ and hydrochlorothiazide $25 \mathrm{mg}$ provides the full additive antihypertensive effect of the components: a randomized, double-blind, parallel-group study in primary care. Clin Drug Investig. 2009;29(5):293-304.

40. Bramlage P, Schonrock E, Odoj P, Wolf WP, Funken C. Importance of a fixed combination of AT1-receptor blockade and hydrochlorothiazide for blood pressure lowering in cardiac risk patients. A postmarketing surveillance study with Candesartan/HCTZ. MMW Fortschritte der Medizin. 2008;149(Suppl 4):172-181.

41. Uen S, Un I, Fimmers R, Vetter H, Mengden T. Effect of candesartan cilexetil with hydrochlorothiazide on blood pressure and ST-segment depression in patients with arterial hypertension. Deutsche medizinische Wochenschrift (1946). 2007;132(3):81-86.

42. Bönner G. Antihypertensive efficacy and tolerability of candesartan-hydrochlorothiazide $32 / 12.5 \mathrm{mg}$ and $32 / 25 \mathrm{mg}$ in patients not optimally controlled with candesartan monotherapy. Blood Press. 2008; 17(Suppl 2):22-30.

43. Ohma KP, Milon H, Valnes K. Efficacy and tolerability of a combination tablet of candesartan cilexetil and hydrochlorothiazide in insufficiently controlled primary hypertension - comparison with a combination of losartan and hydrochlorothiazide. Blood Press. 2000;9(4):214-220.

44. König W. Comparison of the efficacy and tolerability of combination tablets containing candesartan cilexetil and hydrochlorothiazide or losartan and hydrochlorothiazide in patients with moderate to severe hypertension: Results of the CARLOS-Study. Clin Drug Invest. 2000; 19(4):239-246.

45. Bramlage P, Hasford J. Blood pressure reduction, persistence and costs in the evaluation of antihypertensive drug treatment-a review. Cardiovasc Diabetol. 2009;8:18.

46. Simons LA, Ortiz M, Calcino G. Persistence with antihypertensive medication: Australia-wide experience, 2004-2006. Med J Aust. 2008, 188(4):224-227.

47. Sjolie AK, Klein R, Porta M, et al. Effect of candesartan on progression and regression of retinopathy in type 2 diabetes (DIRECT-Protect 2): a randomised placebo-controlled trial. Lancet. 2008;372(9647):1385-1393.
48. Chaturvedi N, Porta M, Klein R, et al. Effect of candesartan on prevention (DIRECT-Prevent 1) and progression (DIRECT-Protect 1) of retinopathy in type 1 diabetes: randomised, placebo-controlled trials. Lancet. 2008;372(9647):1394-1402.

49. Belcher G, Lunde H, Elmfeldt D, et al. The combination tablet of candesartan cilexetil $16 \mathrm{mg}$ and hydrochlorothiazide $12.5 \mathrm{mg}$ has a tolerability profile similar to that of placebo [abstract]. $J$ Hypertens. 2000;18(Suppl 2):S94.

50. Mengden T, Vetter H, Tousset E, Uen S. Management of patients with uncontrolled arterial hypertension - the role of electronic compliance monitoring, 24-h ambulatory blood pressure monitoring and Candesartan/ HCTZ. BMC Cardiovasc Disord. 2006;6:36.

51. Dickstein K, Cohen-Solal A, Filippatos G, et al. ESC Guidelines for the diagnosis and treatment of acute and chronic heart failure 2008: the Task Force for the Diagnosis and Treatment of Acute and Chronic Heart Failure 2008 of the European Society of Cardiology. Developed in collaboration with the Heart Failure Association of the ESC (HFA) and endorsed by the European Society of Intensive Care Medicine (ESICM). Eur Heart J. 2008;29(19):2388-2442.

52. Pfeffer MA, Swedberg K, Granger CB, et al. Effects of candesartan on mortality and morbidity in patients with chronic heart failure: the CHARM-Overall programme. Lancet. 2003;362(9386):759-766.

53. McMurray JJ, Ostergren J, Swedberg K, et al. Effects of candesartan in patients with chronic heart failure and reduced left-ventricular systolic function taking angiotensin-converting-enzyme inhibitors: the CHARM-Added trial. Lancet. 2003;362(9386):767-771.

54. Granger CB, McMurray JJ, Yusuf S, et al. Effects of candesartan in patients with chronic heart failure and reduced left-ventricular systolic function intolerant to angiotensin-converting-enzyme inhibitors: the CHARM-Alternative trial. Lancet. 2003;362(9386):772-776.

55. Yusuf S, Pfeffer MA, Swedberg K, et al. Effects of candesartan in patients with chronic heart failure and preserved left-ventricular ejection fraction: the CHARM-Preserved Trial. Lancet. 2003;362(9386): $777-781$.

56. Lithell H, Hansson L, Skoog I, et al. The Study on Cognition and Prognosis in the Elderly (SCOPE): principal results of a randomized double-blind intervention trial. J Hypertens. 2003;21(5):875-886.

57. Schrader J, Lüders S, Kulschewski A, et al. The ACCESS Study: evaluation of Acute Candesartan Cilexetil Therapy in Stroke Survivors. Stroke. 2003;34(7):1699-1703.

58. Elliott WJ, Meyer PM. Incident diabetes in clinical trials of antihypertensive drugs: a network meta-analysis. Lancet. 2007;369(9557):201-207.

59. Lam SK, Owen A. Incident diabetes in clinical trials of antihypertensive drugs. Lancet. 2007;369(9572):1513-1514.

60. Lindholm LH, Ibsen H, Dahlof B, et al. Cardiovascular morbidity and mortality in patients with diabetes in the Losartan Intervention For Endpoint reduction in hypertension study (LIFE): a randomised trial against atenolol. Lancet. 2002;359(9311):1004-1010.

61. MacDonald MR, Petrie MC, Varyani F, et al. Impact of diabetes on outcomes in patients with low and preserved ejection fraction heart failure: an analysis of the Candesartan in Heart failure: Assessment of Reduction in Mortality and morbidity (CHARM) programme. Eur Heart J. 2008;29(11):1377-1385.

62. Yusuf S, Ostergren JB, Gerstein HC, et al. Effects of candesartan on the development of a new diagnosis of diabetes mellitus in patients with heart failure. Circulation. 2005;112(1):48-53.

63. Zanchetti A, Elmfeldt D. Findings and implications of the Study on COgnition and Prognosis in the Elderly (SCOPE) - a review. Blood Press. 2006;15(2):71-79.

64. Lindholm LH, Persson M, Alaupovic P, Carlberg B, Svensson A, Samuelsson O. Metabolic outcome during 1 year in newly detected hypertensives: results of the Antihypertensive Treatment and Lipid Profile in a North of Sweden Efficacy Evaluation (ALPINE study). J Hypertens. 2003;21(8):1563-1574.

65. Koh KK, Quon MJ, Han SH, Chung WJ, Lee Y, Shin EK. Antiinflammatory and metabolic effects of candesartan in hypertensive patients. Int J Cardiol. 2006;108(1):96-100. 
66. Derosa G, Cicero AF, Ciccarelli L, Fogari R. A randomized, double-blind, controlled, parallel-group comparison of perindopril and candesartan in hypertensive patients with type 2 diabetes mellitus. Clin Ther. 2003; 25(7):2006-2021.

67. Bilous R, Chaturvedi N, Sjolie AK, et al. Effect of candesartan on microalbuminuria and albumin excretion rate in diabetes: three randomized trials. Ann Intern Med. 2009;151(1):11-20.

68. Trenkwalder P, Lehtovirta M, Dahl K. Long-term treatment with candesartan cilexetil does not affect glucose homeostasis or serum lipid profile in mild hypertensives with type II diabetes. J Hum Hypertens. 1997;11(Supp1 2):S81-S83.

69. Mogensen CE, Neldam S, Tikkanen I, et al. Randomised controlled trial of dual blockade of renin-angiotensin system in patients with hypertension, microalbuminuria, and non-insulin dependent diabetes: the candesartan and lisinopril microalbuminuria (CALM) study. BMJ. 2000;321(7274):1440-1444.

70. Burgess E, Muirhead N, Rene de CP, Chiu A, Pichette V, Tobe S. Supramaximal dose of candesartan in proteinuric renal disease. J Am Soc Nephrol. 2009;20(4):893-900.

71. Haller H, Viberti GC, Mimran A, et al. Preventing microalbuminuria in patients with diabetes: rationale and design of the Randomised Olmesartan and Diabetes Microalbuminuria Prevention (ROADMAP) study. J Hypertens. 2006;24(2):403-408.

72. Bakris GL, Toto RD, McCullough PA, Rocha R, Purkayastha D, Davis P. Effects of different ACE inhibitor combinations on albuminuria: results of the GUARD study. Kidney Int. 2008;73(11):1303-1309.
73. Chaturvedi N, Porta M, Klein R, et al. Effect of candesartan on prevention (DIRECT-Prevent 1) and progression (DIRECT-Protect 1) of retinopathy in type 1 diabetes: randomised, placebo-controlled trials. Lancet. 2008;372(9647):1394-1402.

74. Hubner R, Hogemann AM, Sunzel M, Riddell JG. Pharmacokinetics of candesartan after single and repeated doses of candesartan cilexetil in young and elderly healthy volunteers. J Hum Hypertens. 1997;11(Supp1 2): S19-S25

75. Hansson L, Lithell H, Skoog I, et al. Study on COgnition and Prognosis in the Elderly (SCOPE): baseline characteristics. Blood Press. 2000;9(2-3):146-151.

76. Zanchetti A, Elmfeldt D. Findings and implications of the Study on COgnition and Prognosis in the Elderly (SCOPE) - a review. Blood Press. 2006;15(2):71-79.

77. Cohen-Solal A, McMurray JJ, Swedberg K, et al. Benefits and safety of candesartan treatment in heart failure are independent of age: insights from the Candesartan in Heart failure - Assessment of Reduction in Mortality and morbidity programme. Eur Heart J. 2008;29 (24): 3022-3028.

78. Plosker GL, Keam SJ. Candesartan cilexetil: a pharmacoeconomic review of its use in chronic heart failure and hypertension. Pharmacoeconomics. 2006;24(12):1249-1272.
Vascular Health and Risk Management

\section{Publish your work in this journal}

Vascular Health and Risk Management is an international, peerreviewed journal of therapeutics and risk management, focusing on concise rapid reporting of clinical studies on the processes involved in the maintenance of vascular health; the monitoring, prevention and treatment of vascular disease and its sequelae; and the involvement of

\section{Dovepress}

metabolic disorders, particularly diabetes. This journal is indexed on PubMed Central and MedLine. The manuscript management system is completely online and includes a very quick and fair peer-review system, which is all easy to use. Visit http://www.dovepress.com/ testimonials.php to read real quotes from published authors. 